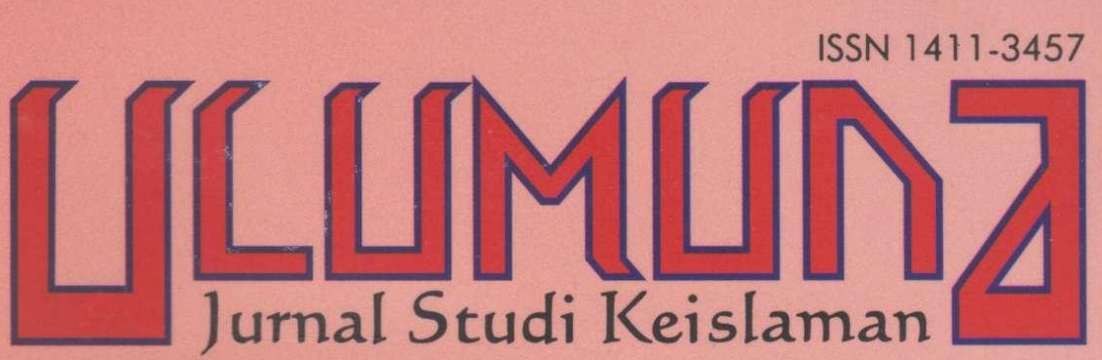
Volume XIV• Nomor 1• Juni 2010

TERAKREDITASI Berdasarkan SK Dirjen Dikti Depdiknas Nomor: 65a/DIKTL/Kep/2008

FILSAFAT ISLAM: ANTARA DUPLIKASI DAN KREASI Abdullah Satar

AL-HIKMAH AL-MUTA'ÂLIYAH: PEMIKIRAN METAFISIKA EKSISTENSIALISTIK MULLA SHADRA Sholihan

HERMENEUTIKA AL-QUR'AN: ANTARA PEMAKNAAN TEKSTUAL DAN KONTEKSTUAL Slamet Mulyono R

MENIMBANG KEMBALI PARADIGMA FILSAFAT ISLAM DALAM BANGUNAN KEILMUAN ISLAM KONTEMPORER Aksin Wijaya

KONTRIBUSI FILSAFAT ILMU DALAM STUDI ILMU AGAMA ISLAM: TELAAH PENDEKATAN FENOMENOLOGI Mulyadi

SIGNIFIKANSI TEORI POPPER, KUHN, DAN LAKATOS TERHADAP PENGEMBANGAN ILMU-ILMU KEISLAMAN Ahmad Choirul Rofiq 
TransLiterasi

Artikel

Abdullah Sattar

Sholihan

Suhermanto Ja'far

Abdul Mukti Ro'uf

Aksin Wijaya

Mulyadi

Slamet Muliono R. Hermeneutika Al-Qur'an:

Antara Pemaknaan Tekstual

dan Kontekstual • 101-120

Menimbang Kembali Paradigma Filsafat

Islam dalam Bangunan Keilmuan Islam

Kontemporer $\bullet 121-144$

Konstribusi Filsafat Ilmu dalam

Studi Ilmu Agama Islam: Telaah

Pendekatan Fenomenologi • 145-176

Ahmad Choirul Rofiq Signifikansi Teori Popper, Kuhn, dan

Lakatos terhadap Pengembangan

Ilmu-Ilmu Keislaman • 177-196

Win Usuluddin

Elusidasi Filosofis Kebhinekaan

Keagamaan: Refleksi atas Pluralisme

Keberagamaan Era Postmodern • 197-226

\section{INDEKS}




\section{PEDOMAN TRANSLITERASI}

\begin{tabular}{|c|c|c|c|c|c|}
\hline Arab & & Latin & Arab & & Latin \\
\hline 1 & $=$ & $\mathrm{a}$ & ف & $=$ & $\mathrm{f}$ \\
\hline ب & $=$ & b & ق & $=$ & $q$ \\
\hline ت & $=$ & $\mathrm{t}$ & ك5 & $=$ & $\mathrm{k}$ \\
\hline$\dot{H}$ & $=$ & ts & J & $=$ & 1 \\
\hline ج & $=$ & j & 5 & $=$ & $\mathrm{m}$ \\
\hline$\tau$ & $=$ & $\underline{\mathrm{h}}$ & ن ن & $=$ & $\mathrm{n}$ \\
\hline$\dot{\tau}$ & $=$ & $\mathrm{kh}$ & و & $=$ & $\mathrm{w}$ \\
\hline د & $=$ & $\mathrm{d}$ & 。 & $=$ & $\mathrm{h}$ \\
\hline ذ & $=$ & $\mathrm{d} z$ & $\Leftrightarrow$ & $=$ & , \\
\hline J & $=$ & $\mathrm{r}$ & ي & $=$ & $\mathrm{y}$ \\
\hline j & $=$ & z & & & \\
\hline س & $=$ & $\mathrm{s}$ & & & \\
\hline ش & $=$ & sy & \multirow{2}{*}{\multicolumn{3}{|c|}{$\begin{array}{l}\text { Untuk Madd } \\
\text { dan Diftong }\end{array}$}} \\
\hline ص ص & $=$ & sh & & & \\
\hline ض ض & $=$ & $\mathrm{dl}$ & i & $=$ & â (a panjang) \\
\hline b & $=$ & th & إي - اي & $=$ & $\hat{1}$ (i panjang) \\
\hline ظ & $=$ & $\mathrm{zh}$ & أو - أو & $=$ & û (u panjang) \\
\hline$\varepsilon$ & $=$ & ' & او - - او & $=$ & aw \\
\hline$\dot{\varepsilon}$ & $=$ & gh & أي اي & $=$ & ay \\
\hline
\end{tabular}




\title{
SIGNIFIKANSI TEORI-TEORI POPPER, KUHN, DAN LAKATOS TERHADAP PENGEMBANGAN ILMU-ILMU KEISLAMAN
}

\author{
Ahmad Choirul Rofiq*
}

\begin{abstract}
One of the contemporary problems being experienced by Muslims is their backwardness in current science development. The progress of science in general is currently dominated by the West. Theme of this paper is the development of science and emergence of theories around it. To elaborate the theme the author will first briefly review the sequence of the development of science in the path of bistory to show the positive contributions of Muslims. Next is the analysis of theories proposed by Popper, Kubn and Lakatos. After that, this paper attempt to describe the significance of these theories to the development of Islamic sciences while connecting them with Fąlur Rahman's view about normative Islam and historical Islam in order to obtain an alternative portrait of the direction of future development.
\end{abstract}

Abstrak: Salah satu problem kontemporer yang tengah dihadapi oleh umat Islam adalah keterbelakangan mereka dalam pengembangan sains dewasa ini. Kemajuan sains secara umum saat ini lebih didominasi oleh Barat. Tema tulisan ini adalah perkembangan sains dan kemunculan teori-teori di seputarnya. Untuke mengelaborasi tema itu, maka penulis terlebih dabulu meninjau secara sekilas runtutan perkembangan sains dalam lintasan sejarab untuk menampilkan kontribusi positif umat Islam di dalamnya. Berikutnya adalah kajian terhadap teori-teori yang dicetuskan oleh Popper, Kubn dan Lakatos. Setelah itu, tulisan ini berupaya memerikan signifikansi teori-teori tersebut terbadap pengembangan ilmu-ilmu keislaman sambil menghubungkannya dengan pandangan Fąlur Rahman mengenai Islam normatif dan Islam historis, sehingga diperoleh potret alternatif mengenai arah pengembanganny ke depan.

Keywords: Filsafat Ilmu, Ilmu-Ilmu Keislaman, Falsifikasi, Induksi dan Verifikasi, Shifting of Paradigm.

*Penulis adalah dosen pada Sekolah Tinggi Agama Islam Negeri (STAIN) Ponorogo. email: rofiq8377@yahoo.co.id. 
TULISAN ini beranjak dari perjumpaan dengan problem kontemporer yang sedang dialami umat Islam, terutama ilmuilmu keislaman. Apabila kita menelusuri sejarah umat Islam, tentu dalam benak kita muncul suatu kegundahan dan keprihatinan mendalam. Mengapa jika dikomparasikan dengan kemajuan ilmu secara keseluruhan yang saat ini didominasi kalangan non Islam (Barat), tampak bahwa perkembangan keilmuan dalam Islam relatif terlambat?

Tidak hanya itu, kita pun menyaksikan bahwa pola pikir mayoritas umat Islam sangat cenderung memandang suci terhadap hasil pemikiran keagamaan, ${ }^{1}$ sehingga dengan lantang menunjukkan sikap penolakan kepada setiap upaya koreksi pemikiran Islam yang pada dasarnya jelas-jelas tidak bisa terlepaskan dari pengaruh konstruk historis, sosial, dan budaya pada masa ketika pemikiran Islam tersebut dilahirkan. Bahkan, kita seakan-akan menutup dengan sangat rapat terhadap pintu ijtihad yang sebenarnya mempunyai fungsi amat vital dalam pengembangan ilmu-ilmu keislaman. Apa ikhtiar yang bisa dilakukan untuk memajukan ilmu-ilmu keislaman sehingga nantinya bisa diraih kembali supremasi peradaban yang dulu pernah berada dalam genggaman tangan umat Islam?

Bercermin dari sejarah perkembangan ilmu pada umumnya yang maju dengan begitu pesat, maka dirasa signifikan untuk mengetahui teori-teori yang muncul berkaitan dengan upaya menjelaskan karakteristik perkembangan ilmu. Setelah memahami secara saksama kandungan masing-masing teori, kita berharap mampu mereguk inspirasi yang terdapat di dalamnya dan kemudian mengaplikasikan spiritnya dalam mengembangkan ilmu-ilmu keislaman, sehingga umat Islam beserta konstruksi pemikiran keagamaannya akan senantiasa dapat berjalan seiring dengan dinamika zaman yang terus berubah.

Karena tema tulisan ini adalah perkembangan ilmu dan teoriteori di seputarnya, maka terlebih dahulu tulisan ini akan

${ }^{1}$ Meminjam istilah taqdîs al-afkâr al-dîniyyah (sakralisasi pemikiran keagamaan) yang dilontarkan Mohammed Arkoun dalam Islâm: al-Akblâq wa al-Siyâsah sebagaimana dikutip oleh M. Amin Abdullah, Islamic Studies di Perguruan Tinggi: Pendekatan Integratif-Interkonektif (Yogyakarta: Pustaka Pelajar, 2006), 49-50. 
meninjau secara sekilas mengenai runtutan perkembangan ilmu dalam lintasan sejarah untuk menampilkan kontribusi positif umat Islam dalam proses keilmuan tersebut. Berikutnya dilakukan kajian terhadap intisari teori-teori yang dicetuskan oleh Popper, Kuhn dan Lakatos. Pemilihan ketiga tokoh ini dilakukan karena teori-teori mereka sangat relevan dalam memahami sejarah perkembangan ilmu. Adapun konsep-konsep utama yang terkait dengannya, antara lain conjecture, falsification, demarcation, the third world, scientific revolution, paradigm, normal science, revolutionary science, incommensurability, gestalt, hard core, negative beuristic, protective belt dan positive heuristic. Setelah itu, tulisan ini kemudian berupaya memerikan signifikansi teori-teori tersebut terhadap pengembangan ilmu-ilmu keislaman sambil menghubungkannya dengan pandangan Fazlur Rahman mengenai Islam normatif dan Islam historis, sehingga diperoleh potret alternatif mengenai arah pengembangannya ke depan.

\section{Lintasan Sejarah Perkembangan Ilmu}

Sejarah tentang perkembangan ilmu merupakan suatu kisah kesuksesan dan kemenangan pengetahuan dalam mengalahkan kebodohan. Salah satu pendorong keberhasilan tersebut ialah adanya natural curiosity (rasa ingin tahu secara alamiah) yang amat besar pada diri manusia dan anugerah kemampuan akal yang dapat mengelola (organize) dan merekam (record) setiap pengetahuan yang diperolehnya. Perkembangan ilmu seperti sekarang ini tidak berlangsung secara mendadak, melainkan melalui proses panjang secara bertahap dan melintasi rute perjalanan di berbagai tempat yang tersebar di muka bumi. Kalau saat ini kalangan Barat sedang memegang kendali ilmu, maka sebenarnya pencapaian itu tidak luput pula dari kontribusi bangsa-bangsa lain, termasuk umat Islam.

Perjalanan ilmu diawali jauh sebelum zaman pra Yunani Kuno ketika manusia masih menggunakan peralatan dari batu dalam kehidupannya. Saat itu mereka menorehkan gambargambar di gua, serta mengukir tulang belulang dan bebatuan. Setelah berhasil menemukan besi, tembaga, perak dan perunggu, mereka dapat mengembangkan peradaban tinggi. Di antara peninggalan yang bisa ditemukan adalah peradaban Babylonia 
(Mesopotamia), Mesir, Cina, dan India. Selanjutnya perkembangan beralih ke zaman Yunani Kuno (ancient Greece) ketika muncul tokoh-tokoh pemikir dan ilmuwan yang mengoptimalkan daya nalarnya secara kritis. Mereka antara lain ialah Thales (624-548 SM), Anaximander (611-547 SM), Anaximenes (570-500 SM), Leucippus (450-370 SM), Phytagoras (580-500 SM), Socrates (469-399 SM), Democritus (460-370 SM), Hippocrates (460-377 SM) Plato (427-347 SM), Aristoteles (384-322 SM), Theophrastus (372-287 SM), Archimedes (287$212 \mathrm{SM}$ ), dan lain sebagainya.

Kemudian pada waktu masyarakat Barat memasuki zaman kegelapan (Dark Age) dan berada pada titik nadir, ironisnya pendulum ilmu pengetahuan berpindah kepada umat Islam yang mampu meraih masa keemasan (Golden Age). ${ }^{2}$ Pada waktu itu, peradaban Islam mencapai puncak kejayaannya. Gerakan penerjemahan karya-karya filsafat dan ilmu pengetahuan berharga dari bahasa Yunani, Syria, Sanskrit, dan Pahlavi ke dalam bahasa Arab, terutama yang paling impresif adalah pada masa pemerintahan Khalifah al-Ma'mun (813-833) dengan Bayt al- Hikmah yang pada mulanya adalah pusat penerjemahan dan penelitian yang kemudian menjadi sebuah akademi yang sangat besar. Kegiatan penerjemahan itu berlangsung sangat intensif. Aktivitas-aktivitas ilmiah dikonsenstrasikan di kota-kota metropolitan, misalnya Baghdad, Damaskus, Aleppo, Qayrawan (Kairouan), Fez, Kairo, dan Cordova di bawah naungan dan dukungan sepenuhnya dari pemerintah Islam, sehingga berhasil mentransfer ilmu dari peradaban lain serta selanjutnya mengembangkannya dengan penuh kegemilangan. Kesuksesannya terbukti dengan banyaknya ilmuwan yang hasil pemikirannya kemudian dimanfaatkan oleh Barat sejak abad XII. ${ }^{3}$ Peran dan kontribusi umat Islam saat itu sangat

${ }^{2}$ Rizal Muntasyir, "Sejarah Perkembangan Ilmu”, dalam Tim Dosen Filsafat Ilmu Fakultas Filsafat UGM, Filsafat Ilmu (Yogyakarta: Liberty, 2003), 63-74; David Burnie, "Science", dalam CD Encarta Reference Library (Washington: Microsoft Corporation, 2005).

${ }^{3}$ Mehdi Nakosteen, History of Islamic Origins of Western Education A.D. 8001350 with an Introduction to Medieval Muslim Education (Colorado: University of Colorado Press, 1964), 144-5; Mohammed Arkoun, Rethinking Islam, ter. Robert. D. Lee (Oxford: Westview Press, 1994), 79. 
mengagumkan dan benar-benar diakui oleh para sejarawan ternama, seperti John William Draper, Guizot, John Davenport, Stanley Lane-Poole, M.P.E. Berthelot, E.J. Homyard, Max Meyerhof, George Sarton dan Philip K. Hitti. ${ }^{4}$ Namun sangat disayangkan, saat ini umat Islam menderita keterpurukan dan bahkan wacana pemikiran Islam mengalami kemandegan karena tradisi Islam tidak dianalisa secara kritis, tetapi hanya diterima begitu saja. ${ }^{5}$ Aktivitas rutin yang biasanya dilakukan sebagian besar kalangan penulis-penulis muslim biasanya hanya menghasilkan karya-karya komentar terhadap karya-karya sebelumnya, bukan diarahkan secara aktif untuk mendapatkan penemuan-penemuan baru yang orisinal, ${ }^{6}$ meskipun sebenarnya harus diakui pula bahwa tidak semua pemikiran-pemikiran Islam unoriginal dan berisi pengulang-ulangan (repitition) semata, karena ada juga ketajaman penalaran di dalamnya. ${ }^{7}$

Peralihan peradaban dari Islam ke Barat dimulai dengan terjalinnya kontak antara keduanya melalui Spanyol ketika orangorang Kristen dan Yahudi bertindak sebagai perantara dan penerjemah. Saat itu pemerintah Islam sangat toleran terhadap penganut agama lain. Bangsa Yahudi yang di Eropa tidak diizinkan hidup justru mendapatkan posisi-posisi yang tinggi di negara-negara Islam. Abad XII menunjukkan adanya program penerjemahan besar-besaran terhadap karya-karya berbahasa Arab ke dalam bahasa Latin. Rute berikutnya melalui Italia, tempat terjadinya kontak dengan Tunisia. Perlu diketahui, bahwa sekolah medis tertua di Eropa bertempat di Salerno dan kemudian disaingi Montpellier, Perancis, yang juga dekat dengan sumber-sumber Arab dan Yahudi. ${ }^{8}$ Bahasa Arab yang menjadi media utama pemikiran ilmiah diajarkan secara sistematis di beberapa universitas dan sekolah Eropa, terutama di Toledo

${ }^{4}$ Muhammad Abdur Rahman Khan, Sumbangan Umat Islam terhadap Ilmu Pengetahuan dan Kebudayaan, ter. Adang Affandi (Bandung: Remaja Rosdakarya, 1996), 84.

${ }^{5}$ Arkoun, Rethinking ..., 2-5.

${ }^{6}$ Fazlur Rahman, Islam and Modernity: Transformation of an Intellectual Tradition (Chicago: The University of Chicago Press, 1982), 38.

${ }^{7}$ Ibid., 151.

8Jerome R. Ravertz, Filsafat Ilmu: Sejarah \& Ruang Lingkup Bahasan, ter. Saut Pasaribu (Yogyakarta: Pustaka Pelajar, 2009), 19-21. 
(Spanyol), Napoli, Bologna (Italia), Narbonne, dan Paris (Perancis). ${ }^{9}$ Oleh karena itu, tidak heran apabila ada ungkapan "Jika orang Yunani adalah bapak metode ilmiah, maka orang Islam adalah bapak angkatnya."10

Pada abad XIV muncul krisis zaman pertengahan yang berlangsung sampai abad XV, dan berikutnya pada abad XV sampai XVI gerakan Renaissance mulai mendominasi. Di antara ilmuwan ternama pada masa Renaissance adalah Nicolaus Copernicus (1473-1543) dengan teori Heliosentris dalam De Revolutionibus Orbium Coelestium yang meruntuhkan teori Geosentris Ptolemy. ${ }^{11}$ Kemudian perjalanan ilmu memasuki masa modern abad XVII dengan rintisan dari Rene Descartes (1596-1650), yang dianggap sebagai bapak filsafat modern. Semenjak itu perkembangan ilmu di Barat semakin maju dengan sangat pesat hingga sekarang. ${ }^{12}$

Sejarah perkembangan ilmu yang demikian cepat itu selanjutnya dianalisis oleh para cendekiawan sehingga melahirkan teori-teori mengenai karakteristik perkembangan ilmu. Di antara mereka adalah Sir Karl Raimund Popper (19021994), Thomas Samuel Kuhn (1922-1996) dan Imre Lakatos (1922-1974) yang akan dikaji dalam tulisan ini.

\section{Karl Raimund Popper}

Meski Karl Raimund Popper, selanjutnya disebut Popper, ${ }^{13}$ banyak mengenal anggota Lingkaran Wina (Vienna Circle) yang

${ }^{9}$ Khan, Sumbangan ..., 86.

10Koento Wibisono Siswomihardjo, "Ilmu Pengetahuan: Sebuah Sketsa Umum mengenai Kelahiran dan Perkembangannya sebagai Pengantar untuk Memahami Filsafat Ilmu", dalam Tim Dosen Filsafat Ilmu Fakultas Filsafat UGM, Filsafat Ilmu (Yogyakarta: Liberty, 2003), 4.

${ }^{11}$ Sebenarnya kritikan terhadap teori Ptolemy telah dilancarkan ilmuwan Islam. Di antaranya Jâbir bin 'Aflah, al-Bitrûjî̀, al-Zarqâlî, Nashîr al-Dîn alThûsî dan al-Battânî. Bahkan Copernicus mengakui jasa-jasa al-Zarqâlî dan al-Battânî. Lihat, Khan, Sumbangan ...., 77-8.

12Ravertz, Filsafat ..., 32-76; Muntasyir, Sejarah ..., 76-84.

${ }^{13}$ Sir Karl Raimund Popper adalah filosuf yang lahir di Wina, Austria, pada 28 Juli 1902 dan meninggal di Croydon, Inggris, pada 17 September 1994. Karya-karyanya antara lain Logik der Forschung (1934) atau The Logic of Scientific Discovery (1959), The Poverty of Historicism (1936), The Open Society and 
cenderung pada positivisme logis, dan sering melakukan kontak (misalnya dengan Viktor Kraft dan Herbert Feigl), namun ia tidak pernah menjadi anggota kelompok tersebut, bahkan ia tidak pernah menghadiri pertemuan-pertemuan mereka. Ia sendiri melontarkan pemikirannya disebabkan penolakannya terhadap pemikiran-pemikiran kelompok tersebut, dan ia menyebut dirinya sebagai kritikus paling tajam terhadap mereka. Pemikiran filosofis Popper meliputi antara lain persoalan induksi, verifikasi, konjektur, demarkasi, falsifikasi, dan dunia tiga. ${ }^{14}$

Popper secara tegas membantah dan menyanggah konsep induksi dan verifikasi yang banyak dikembangkan oleh para filosof sebelumnya, misalnya Lingkaran Wina, terutama Rudolf Carnap (1891-1970). ${ }^{15}$ Metode induksi berarti juga metode proses generalisasi yang bertitik pangkal pada pemeriksaan yang teliti dan telaten mengenai data-data partikular. Kemudian metode induksi terus menjadi asas bagi para ilmuwan dan hampir tidak pernah diperdebatkan. Teori apa saja akan dinilai benar dengan cara penarikan kesimpulan berdasarkan kepada metode induksi. Metode ini menjadi karakter dalam ilmu-ilmu pengetahuan dengan melakukan generalisasi dari hal-hal yang partikular atau dikatakan juga metode induksi berangkat dari beberapa kasus partikular kemudian dipakai untuk menciptakan hukum umum. Misalnya, berdasarkan pengamatan terhadap beberapa angsa yang ternyata berwarna putih, maka dengan melakukan induksi dapat dibuat teori yang lebih umum bahwa semua angsa berwarna putih, atau berdasarkan penelitian bahwa emas

Its Enemies (1945), Conjectures and Refutations: The Growth of Scientific Knowledge (1963), Quantum Theory and the Schism in Physics (1982), The Open Universe: An Argument for Indeterminism (1982), Realism and the Aim of Science (1983), Objective Knowledge: An Evolutionary Approach (1972), Knowledge and the Mind-Body Problem: In Defence of Interaction, (1994), The World of Parmenides (1998), Frübe Schriften (2006), After 'The Open Society': Selected Social and Political Writings (2008). Lihat, www.en.wikipedia.org, diakses tanggal 16 Januari 2010.

${ }^{14}$ Muhammad Muslih, Filsafat Ilmu (Yogyakarta: Belukar, 2004), 119-120.

15 Imre Lakatos, "Falsification and the Methodology of Scientific Research Programmes", dalam Imre Lakatos dan Alan Musgrave (eds.), Criticism and the Growth of Knowledge (Cambridge: Cambridge University Press, 1984), 178. 
dipanaskan memuai, besi dipanaskan memuai, tembaga dipanaskan memuai, lalu disimpulkan bahwa semua logam dipanaskan memuai. Bagi Popper, jika ada pernyataan bahwa semua angsa berbulu putih dan kemudian ditemukan seekor angsa yang berbulu hitam maka pernyataan semula menjadi runtuh dengan sendirinya. ${ }^{16}$

Selanjutnya Popper juga dihadapkan pada masalah demarkasi (pemisahan atau garis batas antara ungkapan ilmiah dan tidak ilmiah sebuah pengetahuan, serta antara ilmu sejati dan ilmu semu) dan verifikasi, baik yang dikembangkan oleh filosof dalam lingkaran Wina maupun di luar Wina sendiri. Verifikasi telah memproklamirkan diri sebagai satu-satunya metode untuk menguji status keilmiahan sebuah teori, sehingga dapat mempertanyakan apakah sesuatu itu meaningful (memiliki arti) atau bersifat meaningless (tidak berarti), juga untuk menilai apakah suatu ilmu dapat disebut dengan ilmu sejati (true science) atau ilmu semu (pseudo science). Artinya, jika suatu pernyataan atau dugaan dapat diverifikasi, maka ia berarti bermakna, sebaliknya apabila tidak dapat diverifikasi maka berarti ia tidak bermakna. Prinsip verifikasi menyatakan bahwa suatu proposisi adalah bermakna jika ia dapat diuji dengan pengalaman dan dapat diverifikasi dengan pengamatan (observasi). Sebagai akibat dari prinsip tersebut maka filsafat tradisional, seperti pembahasan mengenai ada yang absolute, haruslah ditolak. Karena ungkapanungkapannya melampaui pengalaman dan tidak dapat untuk diamati, terlebih lagi untuk diuji, termasuk juga hal-hal yang berkenaan dengan teologi atau metafisika. Mengenai persoalan ini, Popper juga dengan keras melontarkan kritikannya. Menurutnya, hukum-hukum umum dalam ilmu pengetahuan tidak pernah dapat diverifikasi karena, seperti halnya metafisika, harus diakui bahwa seluruh ilmu pengetahuan alam (yang sebagian besar terdiri dari hukum-hukum umum) adalah tidak bermakna. Berdasarkan prinsip verifikasi, maka metafisika dapat dinilai tidak bermakna. Tetapi dalam sejarah disaksikan bahwa acapkali ilmu pengetahuan lahir dari pandangan-pandangan metafisis atau bahkan mistis tentang dunia. Suatu ungkapan

16Muslih, Filsafat ..., 120-2. 
metafisis bukan saja dapat bermakna tetapi bisa juga benar, meski baru menjadi ilmiah kalau sudah diuji. ${ }^{17}$

Mengenai konjektur (dugaan) dan refutasi (penolakan), Popper mengemukakan bahwa kemajuan ilmu pengetahuan dapat melalui conjectures yang merupakan solusi tentatif terhadap suatu persoalan, dan kemudian dikontrol dengan criticism (analisa kritis) yang berupa refutations (upaya penyanggahan) secara tajam. Baginya, ilmu adalah suatu revolusi secara permanen (revolution in permanence), dan jantung aktivitas keilmuan (heart of scientific enterprise) adalah criticism. ${ }^{18}$ Selanjutnya, Popper mengajukan kriteria mengenai sifat ilmiah pengetahuan dengan mensyaratkan adanya kemungkinannya untuk bisa disalahkan (falsifiability), bisa disangkal (refutability) dan bisa diuji (testability). ${ }^{19}$ Selama suatu teori bisa bertahan dalam upaya falsifikasi, maka teori itu akan semakin kokoh (corroborative), meskipun ciri kesementaraannya tetap tidak hilang. Prinsip falsificationism menilai bahwa semua teori ilmiah selalu mengandung potensi untuk dilakukan penyangkalan dan penyanggahan. Apabila suatu teori sudah dapat disangkal (falsified), maka secara otomatis harus digugurkan (eliminated) untuk digantikan teori yang lain. ${ }^{20}$ Contoh kasusnya adalah ketika teori Albert Einstein (1879-1955) berhasil meruntuhkan teori fisika Sir Isaac Newton (1642-1727). ${ }^{21}$

Adapun mengenai teori dunia tiga, Popper menyatakan bahwa realitas terdiri dari tiga dunia, yaitu: [1] dunia satu, yakni the material world atau dunia materi yang bersifat fisik (physical); [2] dunia dua, yakni the world of consciousness atau dunia kesadaran yang bersifat subjektif; [3] dunia tiga, yakni the world of propositions, the world of objective knowledge (dunia proposisi, dunia pengetahuan objektif). ${ }^{22}$ Oleh karena konsep inilah, maka Popper termasuk penganut objectivism yang bertentangan dengan relativism yang

${ }^{17}$ Ibid., 123.

18 Karl R. Popper, Conjectures and Refutations: The Growth of Scientific Knowledge (London: Routledge and Kegan Paul, 1972), vii;

${ }^{19}$ Popper, Conjectures ..., 37.

${ }^{20}$ Lakatos, Falsification ..., 108.

${ }^{21}$ Ibid., 92.

22Ibid., 180. 
diikuti Kuhn. 23 Menurutnya, dunia tiga hanya ada selama dihayati, dalam arti berupa karya dan penelitian ilmiah. Sesudah penghayatan itu, semuanya langsung mengendap dalam bentuk fisik alat-alat ilmiah, buku-buku, karya seni, dan seterusnya. Dengan mengendapnya itu semua, maka hal-hal itu telah menjadi bagian dari dunia satu, namun bisa bangkit menjadi dunia tiga kembali, berkat perhatian dunia dua. Pemikiran ini akan terlihat manfaatnya, terutama dalam memahami konsep falsifikasi. Jika suatu teori mengalami keruntuhan setelah dilakukan kritik, maka pada dasarnya kenyataan dunia satu tidak mengalami perubahan. ${ }^{24}$

\section{Thomas Samuel Kuhn}

Sebagai respon terhadap pandangan kaum positivisme logis (misalnya tentang metode induksi) ${ }^{25}$ dan Popper (misalnya tentang metode falsifikasi), maka Kuhn 26 selanjutnya melontarkan gagasannya yang disebutnya scientific revolution (revolusi ilmu) dengan penekanan pada peran paradigma dalam The Structure of Scientific Revolutions. Karyanya tersebut pertama kali termuat sebagai artikel di dalam the International Encyclopedia of Unified Science yang diterbitkan oleh kalangan positivistik logis dari Vienna Circle. Para peneliti melihat banyak persamaan (similaraties) antara gagasan Kuhn ini dengan pemikiran Michael Polanyi, meskipun terminologi yang mereka pergunakan berbeda. Para pendukung Polanyi mengkritik bahwa Kuhn telah melakukan plagiarisme karena Kuhn sebelumnya beberapa kali

${ }^{23}$ Richard J. Bernstein, Beyond Objectivism and Relativism: Science, Hermeneutics and Praxis (Philadelphia: University of Pennsylvania Press, 1983), 69.

${ }^{24}$ Muslih, Filsafat ..., 124-5.

${ }^{25}$ Kuhn secara tegas mengatakan bahwa dirinya bukan seorang inductivist. Lihat, Kuhn, Logic ..., 16/8; Lakatos, Falsification ..., 178.

${ }^{26}$ Thomas Samuel Kuhn lahir pada 18 Juli 1922 di Cincinnati, Ohio dan meninggal pada 17 Juni 1996 di Amerika. Karya-karyanya antara lain The Structure of Scientific Revolutions (1962), The Copernican Revolution: Planetary Astronomy in the Development of Western thought (1957), The Essential Tension: Selected Studies in Scientific Tradition and Change (1977), Black-Body Theory and the Quantum Discontinuity (1987) dan The Road since Structure: Philosophical Essays (2000) Lihat: www.en.wikipedia.org, diakses tanggal 15 Februari 2010 
menghadiri kuliah Polanyi dan mereka berdua sering terlibat diskusi mengenai tema tersebut. Demi meredam ketegangan antara mereka, maka pada edisi kedua The Structure of Scientific Revolutions (1970) Kuhn menyebutkan bahwa Polanyi secara brilian telah membahas tema yang sangat mirip. ${ }^{27} \mathrm{Di}$ samping itu, meskipun tulisan Kuhn mengenai revolusi ilmu sebagai tanggapan terhadap Popper, pada dasarnya mereka berdua juga sepakat bahwa proses perkembangan ilmu tidak bersifat akumulatif (by accretion), tetapi melalui proses revolusioner (revolutionary process) ketika teori/paradigma lama diganti dengan yang baru. ${ }^{28}$ Contoh paling meyakinkan yang dipakai Kuhn misalnya, ketika teori Heliosentris Copernicus berhasil meruntuhkan teori Geosentris Ptolemy atau pada saat teori Newton tentang gerak digeser oleh teori relativitas Einstein. ${ }^{29}$ Menurut Kuhn, revolusi ilmu ditandai dengan adanya pergantian paradigma (paradigm shifting), meskipun, ia sendiri tidak menyampaikan istilah itu, yang melalui proses mulai dari: [1] prailmu (prescience) ketika tidak memiliki paradigma sentral; [2] ilmu biasa (normal science) ketika ilmuwan mencoba mengembangkan paradigma sentral melalui pemecahan teka-teki (puzzle solving); [3] keganjilan (anomalies) ketika ilmuwan mengalami kegagalan untuk menyesuaikan paradigma; [4] kegentingan (crisis) ketika paradigma benar-benar pada puncak anomali, dan [5] ilmu revolusioner (revolutionary science) ketika paradigma baru muncul. Demikian proses perkembangannya berlangsung seterusnya. ${ }^{30}$

Mengenai pengertian paradigma, Kuhn ternyata tidak secara konsisten menjelaskannya. Margareth Masterman mencatat minimal ada duapuluh satu makna yang terkandung dalam paradigma. ${ }^{31}$ Bahkan muncul kritik yang mengatakan bahwa

27 "Michael Polanyi has briliantly developed a very similar theme." Lihat, Kuhn, The Structure of Scientific Revolutions (Chicago: The University of Chicago Press, 1970), 44.

28 "Revolutionary process" disebut juga "the revolutionary overthrow of an accepted theory and its replacement by a better one". Lihat, Kuhn, Logic ..., 1-2.

${ }^{29} \mathrm{Kuhn}$, The Structure, 68/98.

${ }^{30}$ www.en.wikipedia.org, diakses tanggal 20 Maret 2010.

${ }^{31}$ Kutipan selengkapnya mengenai 21 pernyataan Kuhn itu dapat dilihat pada Margareth Masterman, "The Nature of a Paradigm", dalam Criticism ...., 61-5. 
Kuhn sengaja menggelembungkan makna paradigma untuk membuat pandangan-pandangannya meyakinkan, walaupun akibatnya justru membuat konsep tersebut menjadi semakin tidak jelas dan bahkan telah menjadi penghalang kita untuk memahami beberapa aspek penting dari ilmu pengetahuan itu sendiri. Berdasarkan pemahaman terhadap arti paradigma, sebenarnya pengertian paradigma setidaknya mencakup sebagai berikut. Pertama, generalisasi simbolis (shared symbolic generalizations), yakni anggapan-anggapan atau asumsi-asumsi teoritis pokok yang diyakini bersama, yang tidak dipertanyakan lagi kebenarannya. Kedua, model-model (models), yakni analogi atau perumpamaan mengenai gejala yang dipelajari, dan disepakati sebagai "alat perantara" (beuristic device) untuk melakukan penelitian. Ketiga, nilai-nilai (values), yang berarti bahwa komunitas ilmuwan pada dasarnya menganut nilai-nilai tertentu dalam kegiatan ilmiahnya. Keempat, prinsip-prinsip metafisik (metaphysical principles), yakni asumsi-asumsi yang tidak perlu diuji tetapi menentukan arah penelitian. Kelima, masalahmasalah konkrit (exemplar or concrete problem situations), yakni masalah-masalah yang dipelajari beserta cara penyelesaiannya. Terlepas dari itu semua, upaya Kuhn untuk memahami dan menjelaskan perkembangan ilmu pengetahuan telah berada pada jalur yang benar, sehingga kita dapat terhindar dari pandangan yang sempit yang melihat ilmu pengetahuan seakan-akan hanya terdiri dari teori-teori saja, tetapi juga memperhatikan unsurunsur lain yang terkait dengan teori. ${ }^{32}$ Di samping itu, paradigma sesungguhnya mempunyai hubungan erat dengan teori. Ketika memutuskan untuk mengikuti suatu paradigma tertentu dan teori-teori yang muncul dalam lingkungan paradigma tersebut, maka para ilmuwan telah siap untuk mengarahkan dirinya hanya akan berkutat dengan masalah-masalah yang terletak dalam batas-batas lingkaran wilayah paradigma dan teori-teori pilihannya itu saja. ${ }^{33}$

${ }^{32}$ Lihat Heddy Shri Ahimsa-Putra, Paradigma dan Revolusi Ilmu dalam Antropologi Budaya: Sketsa Beberapa Episode dalam Naskah Pidato Pengukuhan Jabatan Guru Besar di Universitas Gadjah Mada, Yogyakarta pada 10 November 2008, 4-6.

${ }^{33}$ Abdullah, Islamic ..., 42. 
Persaingan yang terjadi antar paradigma (rival paradigms), menurut Kuhn, bersifat tidak bisa diukur (incommensurable), sehingga menimbulkan penilaian bahwa pemilihan teori menjadi tidak rasional (irrational) dan pandangan tersebut bersifat relativistik. ${ }^{34}$ Memang tema mengenai konsep incommensurability termasuk yang paling kontroversial, meskipun tidak hanya Kuhn yang melontarkannya, tetapi juga Feyerabend (koleganya di Universitas California di Berkeley pada 1950-an). Tema inilah yang memunculkan perdebatan sengit antara objektivisme dan relativisme. Meskipun ia menyangkal dianggap relativistik, tetapi penelusuran menunjukkan bahwa ia telah menyatakan secara eksplisit mengenai incommensurability beberapa kali di dalam The Structure of Scientific Revolutions. ${ }^{35}$

Dalam pemikiran Kuhn berikutnya, normal science terwujud dengan aktivitas pemecahan teka-teki (purzle solving) ${ }^{36}$ yang diikuti dengan kemapanan suatu paradigma ketika teori-teori tersebut dilestarikan di dalam buku-buku teks pendidikan. Oleh sebab itu, jika telah terjadi revolusi ilmu, sudah seharusnya bukubuku teks tersebut ditulis ulang ${ }^{37}$ dan konsep-konsep atau termaterma lama harus direinterpretasi. ${ }^{38}$ Perubahan paradigma, baik secara keseluruhan maupun sebagian dari unsur-unsurnya, ${ }^{39}$ saat berlangsungnya revolusi inilah yang dapat diserupakan dengan gestalt switch (perubahan gestalt) atau semacam perubahan cara pandang seseorang ketika tanda-tanda di atas kertas yang sebelumnya tampak seperti burung sekarang tampak seperti antelop atau sebaliknya. Apa yang merupakan itik dalam dunia ilmuwan sebelum revolusi, kini menjadi kelinci setelah revolusi. Orang yang mula-mula melihat bagian luar kotak dari atas, selanjutnya melihat bagian dalamnya dari bawah. Orang yang dulu meyakini bulan sebagai planet, sekarang menyadari

${ }^{34}$ www.en.wikipedia.org, diakses tanggal 20 Maret 2010.

35 Kutipan selengkapnya mengenai pernyataan-pernyataan Kuhn dapat dilihat pada Bernstein, Beyond..., 79-82.

${ }^{36}$ Kuhn, The Structure ..., 35.

${ }^{37}$ Ibid., 137.

${ }^{38}$ John Losee, A Historical Introduction to the Philosophy of Science (Oxford: Oxford University Press, 2001), 199.

${ }^{39}$ Kuhn, The Structure ..., 92. 
kesalahannya dan menyebutnya sebagai satelit. ${ }^{40}$ Demikianlah, proses perkembangan ilmu berlangsung seterusnya karena kemunculan anomali-anomali akan senantiasa dijumpai dan tidak pernah benar-benar habis (never complitely exhausted). ${ }^{41}$

\section{Imre Lakatos}

Pada perkembangan sesudah kemunculan teori-teori Popper dan Kuhn, maka kemudian tampil gagasan dari Imre Lakatos 42 yang disebutnya The Methodology of Scientific Research Programmes. Pemikirannya ini merupakan upayanya untuk menjembatani konflik antara Popper dan Kuhn, ${ }^{43}$ sekaligus sebagai perbaikan dari gagasan paradigma yang diusulkan Kuhn dan perluasan dari teori falsifikasi yang dikemukakan Popper. Lakatos memberi ruang dan bahkan menggarisbawahi perlu adanya koeksistensi beberapa program riset alternatif pada waktu yang bersamaan dan dalam domain yang sama pula. Menurutnya, kita dapat membandingkan secara objektif kemajuan-kemajuan relatif yang dicapai oleh tradisi-tradisi riset yang saling berlomba. ${ }^{44}$

Program riset melibatkan dua unsur utama, yaitu: [1] negative beuristic: hard core, yakni persoalan inti yang tidak bisa dikembangkan, dan [2] positive beuristic: protective belt, yakni persoalan yang dikembangkan dari persoalan inti dan sebagai sabuk pelindungnya. Program riset dinilai sukses apabila mampu mengarahkan pada kemajuan (progressive problemshift), tetapi dinilai gagal apabila justru mengakibatkan kemunduran (degenerating problemshift). Contoh program riset paling berhasil yang bisa dipergunakan misalnya teori gravitasi Newton yang sebelumnya

40Ibid., 85, 111, dan 115.

${ }^{41}$ Lakatos, Falsification ..., 135.

${ }^{42}$ Imre Lakatos lahir di Debrecen, Hungaria pada 9 Nopember 1922 dan meninggal pada 2 Pebruari 1974 di Inggris. Karya-karyanya antara lain (ed.) Problems in the Philosophy of Mathematics (1967), (ed.) The Problem of Inductive Logic (1968), (editor bersama Alan Musgrave) dalam Problems in the Philosophy of Science (1968) dan Criticism and the Growth of Knowledge (1970), History of Science and Its Rational Reconstructions (1970), Proofs and Refutations: The Logic of Mathematical Discovery (1976) dan The Methodology of Scientific Research Programmes (1978). Lihat, www.en.wikipedia.org, diakses tanggal 20 Maret 2010.

${ }^{43}$ www.en.wik.ipedia.org, diakses tanggal 20 Maret 2010.

${ }^{44}$ Abdullah, Islamic ..., 45-6. 
tenggelam dalam suasana penuh anomali saat itu berhasil menggugurkan teori-teori observasional. Karakteristik hard core adalah ia diterima melalui kesepakatan dan tidak bisa disangkal (irrefutable) oleh pelaksana program riset. Sebaliknya karakteristik protective belt adalah ia bisa disangkal (refutable). Di dalam protective belt itulah dijumpai anomali-anomali yang tidak akan pernah selesai. Positive heuristic sangat bermanfaat dalam menyelamatkan sang ilmuwan dari kesulitan dan kebingungan yang disebabkan anomali-anomali. Dengan demikian, ia lebih fleksible daripada negative heuristic karena senantiasa tumbuh dan berkembang mengikuti perjalanan waktu. ${ }^{45} \mathrm{Di}$ sana pula terdapat auxiliary bypotheses (hipotesa-hipotesa bantu) yang diletakkan di sekeliling bard core. ${ }^{46}$ Tetapi meskipun demikian, dipahami pula bahwa sebenarnya sabuk pelindung itu hanya mengamankan hard core sejauh sesuai dengan perkembangan, saat-saat dan kondisi tertentu. ${ }^{47}$ Dua unsur utama di atas selanjutnya dilengkapi dengan serangkaian teori-teori (a series of theories) yang menjamin bahwa teori-teori tersebut saling berkaitan karena teori yang belakangan senantiasa menyempurnakan teori sebelumnya. ${ }^{48}$

Jadi, pada dasarnya sejarah ilmu telah dan seharusnya merupakan sejarah bagi banyak program riset yang saling bersaing. Oleh karena itu, hal yang diperlukan keberadaannya dalam kegiatan pengembangan ilmu adalah beuristic power (kekuatan pengembangannya) 49 dan continuity (keberlanjutannya). ${ }^{50}$

\section{Signifikansinya terhadap Pengembangan Ilmu-Ilmu Islam}

Setelah menyajikan intisari teori-teori Popper, Kuhn, dan Lakatos mengenai perkembangan ilmu, sekarang pertanyaannya adalah: "Apa benang merah yang menghubungkan ketiga tokoh di atas? Apa ada signifikansi pandangan-pandangan mereka

\footnotetext{
45Lakatos, Falsification ..., 133-7; Losee, A Historical ..., 203.

${ }^{46}$ Losee, A Historical ..., 204.

${ }^{47}$ Abdullah, Islamic ..., 47.

${ }^{48}$ Losee, A Historical ..., 203-4; Abdullah ..., 45.

${ }^{49}$ Ibid., 155.

50Losee, A Historical ..., 202.
} 
terhadap upaya pengembangan ilmu-ilmu keislaman yang tampaknya relatif berjalan lambat?"

Jika ditelusuri kembali kandungan teori-teori mereka, maka dapat dinyatakan bahwa ketiganya sesungguhnya menyepakati bahwa ilmu itu mengalami pertumbuhan dan berproses (on going process dan on going formation), 51 meskipun terma yang digunakan mereka berbeda-beda (misalnya Popper dengan falsification, Kuhn dengan scientific revolutions dan Lakatos dengan research programmes). Pada prinsipnya mereka secara bersama-sama mengakui bahwa ilmu itu tidak ada yang permanen. Hal yang permanen dan terus berlangsung hanyalah perubahannya itu sendiri karena ilmu itu bersifat historis tentatif. Suatu teori atau paradigma akan selalu diperbaiki dan disempurnakan oleh teori atau paradigma lain dari waktu ke waktu karena karakteristiknya yang bisa dikoreksi dan bisa salah. Jika sifat dasar ilmu adalah demikian, maka sifat serupa tentunya juga melekat pada ilmu-ilmu keagamaan, termasuk dalam agama Islam. Pada saat kesadaran positif semacam ini tampil ke permukaan, maka pada saat itu pula teoriteori ketiga pemikir di atas menemukan signifikansinya terhadap pengembangan ilmu-ilmu keislaman.

Dengan merunut perkembangan wacana pemikiran Islam, sebenarnya kita juga menjumpai pandangan yang relevan dengan pandangan mereka bertiga, yaitu pandangan Fazlur Rahman mengenai pembedaan antara Islam normatif (normative Islam) dan Islam historis (bistorical Islam). ${ }^{52}$ Islam normatif merupakan ajaran-ajaran Islam yang bersifat dogmatis yang dalam hal ini diwakili oleh al-Qur'an dan hadist Nabi. Sedangkan Islam historis terwujud ketika doktrin normatif ajaran Islam berinteraksi dengan masyarakat Islam dan kemudian menjadi konstruksi pemikiran yang terdapat dalam ilmu-ilmu keislaman, misalnya tafsir, fiqh, kalam, dan tasawuf.

Lantas bagaimana menyikapi kedua kategori tersebut? Di sinilah terasa arti penting teori-teori ketiga tokoh itu. Misalnya kita meniliknya dari aspek sifat yang terdapat pada Islam normatif dan Islam historis. Tampak bahwa Islam normatif menyerupai hard core/negative heuristic yang tidak bisa disangkal

${ }^{51}$ Mengutip istilah M. Amin Abdullah. Lihat, Abdullah, Islamic ..., 7.

52Rahman, Islam ..., 141. 
maupun difalsifikasi. Adapun Islam historis mempunyai persamaan dengan protective belt/positif heuristic yang bisa disangkal, dikoreksi atau disempurnakan lebih lanjut. Bahkan dalam sejarah agama-agama monotheis, kita menyaksikan bukti penyempurnaan ajaran yang diperlihatkan Tuhan. Contohnya, ketika Tuhan mengutus Muhammad sebagai rasul-Nya, maka kitab Injil digeser oleh kitab al-Qur'an, meskipun prinsip ajaran tauhid (pengesaan Tuhan) tetap dipertahankan, atau ketika arah peribadatan dipindahkan dari Baitul Maqdis ke Ka'bah di Masjidil Haram. Selain itu, kita menyaksikan dalam bidang fiqh ketika al-Syâfi'î mengeluarkan pendapat barunya yang terkenal dengan al-qawl al-jadîd setelah sebelumnya menyampaikan pendapat lamanya yang disebut dengan al-qawl al-qadîm.

Jadi, pada dasarnya praktik perubahan atau pergeseran pemikiran adalah merupakan sesuatu yang wajar dan lumrah karena sifatnya yang tidak kebal dari kesalahan. Hal inilah mungkin yang disadari sepenuhnya oleh para penulis muslim ketika mengakhiri tulisannya selalu dengan ungkapan wa Allâh a'lam bi al-shawâb. Di samping itu, perlu dipahami bahwa bangunan pengetahuan yang tercakup ke dalam Islam historis semula dirintis dan diformulasikan oleh masyarakat yang hidup pada masa tertentu, dan dipengaruhi oleh masalah-masalah dan tantangan-tantangan yang sangat valid bagi konteks waktunya saat itu. Berdasarkan kenyataan bahwa problem dan tantangan itu berbeda dari masa ke masa, maka secara natural konstruksi pengetahuan menjadi selalu terbuka untuk diuji ulang, diteliti, direformulasi dan direkonstruksi oleh para ilmuwan dan peneliti pada setiap kurun waktu. ${ }^{53}$

Termasuk ke dalam wilayah pengembangan protective belt/positif heuristic pada Islam historis adalah optimalisasi ijtihad. Aktivitas berijtihad merupakan penggunaan pemikiran secara sungguh-sungguh untuk menganalisa dan menetapkan suatu hukum Islam. Tetapi bolehkah seseorang berijtihad dalam sesuatu yang dalilnya bersifat qath'î dengan alasan demi kemaslahatan umum atau demi memenuhi keadilan yang kita perkirakan dalam suatu peraturan hukum, sebagaimana sering

${ }^{53}$ Abdullah, Islamic ..., 53-4. 
dilakukan oleh kalangan Islam yang berpikiran liberal? Sebagian orang berkata bahwa hukum-hukum al-Qur'an yang diturunkan di jazirah Arab sekian abad yang lalu hanya sesuai dengan situasi dan kondisi budaya pada waktu itu. Oleh karena itu, tidak semua kandungan al-Qur'an harus diperlakukan bersifat universal. Ada hal-hal yang harus ditata kembali serta diterapkan ijtihad seluasluasnya walaupun terpaksa menyimpang dari nash-nash al-Qur'an dan hadits yang qath'i supaya sesuai dengan perubahan zaman dan demi kepentingan masyarakat.

Pikiran-pikiran semacam itu seharusnya dicermati ulang. Bagaimana jika nanti ada pendapat yang membolehkan kaum pria menikahi sepuluh wanita disebabkan jumlah wanita yang sangat banyak? Bagaimana jika orang menggugat puasa karena dianggap memperlemah produktifitas kerja dan menghambat pembangunan negara? Bagaimana jika diusulkan agar tidak berhaji karena dianggap menghambur-hamburkan uang? Bagaimana jika sholat digantikan dengan aktivitas meditasi semata? Demikianlah, bagaimanapun juga ijtihad itu memang penting dan diperlukan untuk menumbuhkan ruh Islam yang dinamis, menerobos kebekuan, memperoleh manfaat sebesarbesarnya dari ajaran Islam, serta mencari pemecahan Islami untuk masalah-masalah kehidupan kontemporer. Namun, jangan pernah dilupakan bahwa ijtihad tidak boleh dilakukan secara gegabah karena hal itu justru sangat kontra produktif dan akan menimbulkan ekses negatif yang malah bertentangan dengan tujuan mulia dari pemberian ruang dan kesempatan ijtihad itu sendiri. Barangkali semangat ijtihad inilah yang bisa disamakan dengan heuristic power (kekuatan pengembangan ilmu) dan dijadikan sarana bagi pengembangan ilmu-ilmu keislaman. Kita sebagai umat Islam mempunyai kewajiban bersama untuk senantiasa menyalakan obor semangat ijtihad ini dan menjaganya jangan sampai padam.

\section{Catatan Akhir}

Berpijak dari uraian sederhana di atas, tulisan ini hendak mengakhiri pemaparan dengan penutup sebagai berikut. Sudah merupakan suatu kenyataan yang tidak dapat dipungkiri bahwa saat ini posisi umat Islam, terutama di bidang keilmuan, berada 
di belakang umat lain (Barat), meskipun sejarah ilmu telah menunjukkan bahwa umat Islam pernah menorehkan tinta emas dalam peradaban tinggi yang mampu berkontribusi positif terhadap perkembangan ilmu, yang di antaranya juga dimanfaatkan oleh Barat. Oleh karena suatu hikmah itu tidak hanya bisa diperoleh dari umat Islam, tetapi juga bisa dari umat lain, maka bukan suatu aib seandainya kita memungut hikmah dari hasil pemikiran orang-orang luar (Barat), misalnya Karl R. Popper, Thomas S. Kuhn, dan Imre Lakatos.

Pesan yang ingin disampaikan oleh ketiga pemikir itu di antaranya, bahwa sifat dasar ilmu itu ialah keadaannya yang senantiasa tumbuh dan berproses seiring perjalanan waktu demi upaya meraih suatu kesempurnaan secara terus menerus. Karena ilmu itu tidak sempurna, maka ia tidak dapat lepas dari kekurangan dan kekeliruan, sehingga bisa dilaksanakan falsification. Tugas bagi setiap peneliti untuk terus berusaha melakukan perbaikan dan penyempurnaan. Demikian pula terhadap ilmu-ilmu keislaman, terutama yang berada di dalam domain protective belt (Islam historis). Ia sebenarnya tidak imun dari kealpaan, sehingga umat Islam berkewajiban untuk selalu mengembangkannya melalui scientific revolutions atau research programmes dan penerapan ijtihad intelektual secara optimal dengan tetap mengedepankan prinsip kehati-hatian. Wa al-Lâh a lam bi al-shawâb.

\section{Daftar Pustaka}

David Burnie, "Science", dalam CD Encarta Reference Library (Washington: Microsoft Corporation, 2005).

Fazlur Rahman, Islam and Modernity: Transformation of an Intellectual

Tradition (Chicago: The University of Chicago Press, 1982).

Heddy Shri Ahimsa-Putra, Paradigma dan Revolusi Ilmu dalam Antropologi Budaya: Sketsa Beberapa Episode dalam Naskah

Pidato Pengukuhan Jabatan Guru Besar di Universitas Gadjah Mada, Yogyakarta pada 10 November 2008.

Imre Lakatos, "Falsification and the Methodology of Scientific

Research Programmes", dalam Imre Lakatos dan Alan 
Musgrave (eds.), Criticism and the Growth of Knowledge (Cambridge: Cambridge University Press, 1984).

Jerome R. Ravertz, Filsafat Ilmu: Sejarah \& Ruang Lingkup Bahasan, ter. Saut Pasaribu (Yogyakarta: Pustaka Pelajar, 2009).

John Losee, A Historical Introduction to the Philosophy of Science (Oxford: Oxford University Press, 2001).

Karl R. Popper, Conjectures and Refutations: The Growth of Scientific Knowledge (London: Routledge and Kegan Paul, 1972).

Koento Wibisono Siswomihardjo, "Ilmu Pengetahuan: Sebuah Sketsa Umum mengenai Kelahiran dan Perkembangannya sebagai Pengantar untuk memahami Filsafat Ilmu", dalam Tim Dosen Filsafat Ilmu Fakultas Filsafat UGM, Filsafat Ilmu (Yogyakarta: Liberty, 2003).

M. Amin Abdullah, Islamic Studies di Perguruan Tinggi: Pendekatan Integratif-Interkonektif (Yogyakarta: Pustaka Pelajar, 2006).

Mehdi Nakosteen, History of Islamic Origins of Western Education A.D. 800-1350 with an Introduction to Medieval Muslim Education (Colorado: University of Colorado Press, 1964).

Mohammed Arkoun, Rethinking Islam, ter. Robert. D. Lee (Oxford: Westview Press, 1994).

Muhammad Abdur Rahman Khan, Sumbangan Umat Islam terhadap Ilmu Pengetabuan dan Kebudayaan, ter. Adang Affandi (Bandung: Remaja Rosdakarya, 1996).

Muhammad Muslih, Filsafat Ilmu (Yogyakarta: Belukar, 2004).

Richard J. Bernstein, Beyond Objectivism and Relativism: Science, Hermeneutics and Praxis (Philadelphia: University of Pennsylvania Press, 1983).

Rizal Muntasyir, "Sejarah Perkembangan Ilmu", dalam Tim Dosen Filsafat Ilmu Fakultas Filsafat UGM, Filsafat Ilmu (Yogyakarta: Liberty, 2003).

Thomas S. Kuhn, The Structure of Scientific Revolutions (Chicago:

The University of Chicago Press, 1970).

www.en.wikipedia.org, diakses tanggal 16 Januari 2010. 